\title{
POLITENESS IN BAD NEIGHBORS MOVIE
}

\author{
Sastika Seli ${ }^{1}$ \\ STKIP-PGRI Lubuklinggau \\ Dewi Syafitri ${ }^{2}$ \\ STKIP-PGRI Lubuklinggau \\ $\underline{\text { rshellee@yahoo.com }}{ }^{1}$ \\ Submit, 20-04-2018 Accepted, 01-06-2018 Publish, 01-06-2018
}

\begin{abstract}
The research aims at describing politeness used by Americans in Bad Neighbors movie to express apology. This is a qualitative-descriptive research which identified, observed, transcribed the data as well as described them in the sentences. The findings present the strategy of apologizing and the use of address terms overviewed from politeness strategies such as positive politeness, negative politeness and offrecord. The use of address terms in expressing apology covered terms of addressing in negative politeness includes the use of title plus last name (TLN) (such as Mr. Haywood and Ma'am) and positive politeness includes different nick names (NN) (such as Mac, Baby, Scoonie, Guys, etc). The variation of apologizing includes direct apology (sorry and I'm sorry). In the application of direct apology I'm sorry, no address term was used in the expression and it indicates positive politeness. In a direct expression of apology sorry, there was a term of address used preceded the expression and sometimes it also occurred afterward. Based on the description, it can be inferred that most of expression of direct apology expressed in positive politeness because the first speaker wanted to show a more intimate relationship to the second speaker. The position of the terms also affects the purpose and the quality of sincerity of the speakers. This strategy considered to be an effective way to express apology to show that the speaker who committed a responsibility of apologizing regretted the mistakes.
\end{abstract}

Keyword: politeness, apologizing, term of address

\section{INTRODUCTION}

Speaking with someone with different social status and dimension has to be in the appropriate way. He/she has to think the correct words, intonation and norms depend on the interlocutor (hearer) (Hymes in Johnstone and Marcellino, 2010:4-7). If he/she speaks to a baby it will be different to speak with the teacher or a parking 
man. The act of greeting (Good morning), leave-taking expressing something (Good bye), asking for something (Can you...?) and any other speaking activities has to be in the right norm.

Speaking activity requires some norms and appropriate acts. Actually, language provides a variety of ways of saying the same thing in addressing and greeting others, describing things, and paying compliment. Some factors influence the relationship between the people in particular situation and how the speaker feels about the people addressed. Politeness is one important thing to consider to speak with others. According to Holmes (1992:297) there are two different types of politeness. Positive politeness is solidarity oriented. It emphasizes shared attitudes and values. A shift to a more informal style using slang and swear words will function similarly as an expression of positive politeness. Negative politeness corresponds to people respect and avoids intruding on them. Negative politeness involves expressing oneself appropriately in terms of social distance and respecting status differences.

Politeness in different culture might be different. The use of language or English can be seen from movies produced and released in all over the world. Therefore, it would not be a problem to know different politeness in different culture. One of the movies is Bad Neighbors produced by Hollywood reflected the characteristic of American politeness used by Americans in a comedy movie. As we know that American humor is more vulgar and rude to listen and to see. What about the politeness? The research only concerned with politeness in addressing and apologizing to others used in this adult American comedy movie.

\section{LITERATURE REVIEW}

\section{Politeness}

Actually, language provides a variety of ways of saying the same thing in addressing and greeting others, describing things, paying compliment, apologizing and other expressions. Some factors influence the relationship between the people in particular situation and how the speaker feels about the people addressed. Wardaugh (2000:265) stated that one can addressed others by title (T), first name (FN), by last name (LN), by nick name, by some combination of them, or by nothing at all. In addressing another, the choice of name which one uses for the other depends both on the knowledge of the person the addresser speak to, and the situation. Addressing by title alone is the least intimate form of address in that titles usually designate ranks or occupation, as in Colonel, Doctor, or Waiter. When someone uses first name alone in addressing, it seems that the person is presuming an intimacy or alternatively is trying 
to assert some power the addressee. Using nickname shows an even greater intimacy. Both first name and nickname tends to occur in relaxed of informal situation. Title and first name have the interesting effect of showing respect by the title, by intimacy by the first name. In English we are in doubt as to know to address another, we can actually avoid the difficulty by not using any address term at all. We can say "Good morning" as well as "Good morning, Sir/ Mr. Smith".

A shift to a more informal style using slang and swear words will function similarly as an expression of positive politeness. The participants in positive politeness have the same level in communication. The example of the expression of negative politeness system is using title and last name to superior and to older people that one does not know well or using a language in different level.

Leech (cited in Spencer-Oatey, 2004:23) state that a polite speech is a speech which is obeying the norm of maxim and it is not violating the norm of maxim's politeness. They are tact maxim, generosity maxim, modesty maxim, approbation maxim, agreement maxim and sympathy maxim.

1. Act maxim: minimize cost to other. Maximize benefit to other.

2. Generosity maxim: minimize benefit to self. Maximize cost to self.

3. Approbation maxim: minimize dispraise of other. Maximize praise of other.

4. Modesty maxim: minimize praise of self. Maximize of self.

5. Agreement maxim: minimize disagreement between self and other. Maximize agreement between self and other.

6. Sympathy maxim: minimize antipathy between self and other. Maximize sympathy between self and other.

According to Yule (2006:60), politeness is as the means employed to show awareness of another person's face. In this sense, politeness can be accomplished in situations of social distance or closeness. Showing awareness for another person's face when that other seems socially distant is often described in term of respect or deference. Showing the equivalent awareness when the other is socially close is often described in term of friendliness, friendship or solidarity. Holmes (1992:296) state that generally speaking politeness involves taking account of the feelings of others. A polite person makes others feel comfortable. Being linguistically polite involves speaking to people appropriately in light of their relationship

Furthermore, Brown and Levinson (cited in Kedves, 2013:434-436), politeness assumes that we all have face, and we all have face wants and needs. Further, there are different types of face threatened in various face-threatening acts, and sometimes the face threats are to the hearer, while other times they are to the 
speaker. There are positive face, negative face and off-record to state something in a polite way. Positive face wants to show the intimacy from speakers to hearers by saying something casual. Negative face wants to show something politely without intruding the hearers. The last politeness is off-records show that someone is saying the words implicitly that he/she wants to be get attention from the second speakers/hearers.

\section{Terms of Address}

Speaking to someone, one has to say the words appropriately. People cannot just say or call someone without considering about anything. If they meet a teacher on the street, they cannot just say the name because it will be impolite and a breakingnorm. To address someone, it depends on the relationship that we have to someone. Is it close or distant, formal or informal, we cannot just address people with the same forms (Holmes, 1992:16). Other social factors of addressee also influences the way we address someone.

Addressing also considers the norm. Norm binds strongly when we use the language. Different culture different norm, different area different culture, is the rules in using the language. For examples, British English and American English are two English with different dialect (Quirk, 2014:79). Using both of language caused confusion if the users do not know how to use them appropriately.

Address system is usually used to show the possession of formal and informal manners and consideration for other people. In other words, by employing a certain address terms, speaker wants to express his or her feeling of respect, solidarity, intimacy, and familiarity to other people (Wardaugh, 2000:264). Clearly, address terms are employed to maintain social relation that occurs in daily life.

People can find many forms of address term used. In relaxed situation, someone often calls a friend with his nickname, such as Tom for Tommy or Mickey for Michael. However, in other formal situation, people tend to address someone else by their titles like Mr., Mrs., and $D r$, Professor and name which refer to the

profession they have. Besides, the addresses of My Love, My Dear, or title one are usually used to show the intimate relation between the addresser and addressee. Address system is one of the important tools of communication used in society. Address systems of a language correlate highly with social structure (Aliakbari \& Toni, 2008:40). Social class, age, sex, profession, marital status, politeness and another related aspect are the kinds of basic rules of address system. Address system is used by a person to address one he or she talk to, and the use depends on the 
relationship between the addresser, addressee and the relative status of the individual involved in conversation.

According to Afful (2006:92), there are 9 categories of address term. They are personal names (Nick, Stella), title terms (Mr., Miss), occupation-bound terms (Sir, Ma'am), kinship terms (Mom, Dad), terms of formality (Sir, Ma'am), terms of intimacy (Dude, Bro), personal pronouns (you), descriptive phrases (your highness), and zero address terms (using no term of address). They are used in different social and cultural condition in the society. Moreover, Koul (in Jan, 2013:75) mentions interjections of address, kinship terms of address and second person pronominal. In this study, the classification of American address terms found in the movie is based on the two theories from Afful and Koul.

\section{Apologizing}

Apologies was expressive illocutionary acts, which can bedifferentiated from complaint, which was also expressive acts, by beingconvivial in nature. In the terminology of Leech (1999:370), the act ofapologizing was convivial speech act, the goal of which coincides with thesocial goal of maintaining harmony between speaker and hearer (Leech, 1999:373). Meanwhile, Holmes (1992:92) considers apology as a speech actdirected to the addressee's face need and intended to remedy an offensefor which the speaker takes responsibility, and thus to restore equilibriumbetween the speaker and addressee. By apologizing, the speaker has alsopaid the debt created by his/her transgression, thus restoring theinteractional balance Brown and Levinson (1987:21).The speech act of apologizing is rather different from that ofrequesting, since apologies was generally post-event acts, apologies signalthe fact that a certain type of event has already taken place (or the speakermight be aware of the fact that was about to take place). By apologizing, thespeaker recognizes the fact that violation of a social norm has beencommitted and admits to the fact that she or he was at least partially involvedin its cause. Hence, by their very nature, apologies involve loss of face forthe speaker and support for the hearer (Blum-Kulka and Olstain, 1983:18)Meanwhile, when we make mistakes, we will agree thatacknowledging our mistake and offering a sincere apology is a reasonableresponse.

According to Grigsby (2007:97) apology involves the acknowledgement of injury withthe acceptance of responsibility, affect (felt regret or shame-the personmust mean it), and vulnerability- the risking of an acknowledgementwithout excuses. The expression contains some regrets felt by the speakers and expecting a forgive expression from the interlocutor. 
According to Ury, Brett, and Goldberg as cited in Maddux (2011:24) apologies are critical for resolvingdisputes and repairing trust between negotiators. Disputes are typicallycharacterized by anger and a focus on power and rights rather than interest. Apology was a process that involved a change in emotion andattitude regarding an offender. Olshtain and Cohen (1983:234) also say that the act of apologizing was called for when there were some behaviors, which have violated social norm, whether the offense was real orpotential. It was assumed that there was two participants involved in it,namely the apologizer and the recipient of apology. The apologizer was theone who was perceived by the recipient to have the responsibility to state expression of apology. The recipient was the one perceiving her/him as persondeserving of apology. There was also social expectation that the offender orthe apologizer should express an apology for the deed she has committed.The types and the intensity of apology may be different. They may becaused by the different degrees of mistakes in the action or by the differentcircumstance related to the behavior.

Based on the definition above, it can be noted that an apology was conducted when the offender has committed an offensive act (action orutterance), which also means that it has violated social norms, by expressing regret and acknowledging responsibility for the undesirableeffect of the act upon the offended party. Commonly, apologies was intended to remedy the offense. They was different from other convivialacts, such as thanking, congratulation or complaint, by their remedialfunction.

\section{RESEARCH METHOD}

The study is a descriptive research. Descriptive research can be either quantitative or qualitative. In this study, qualitative descriptive approach was conducted to describe the sociolinguistics phenomenon in sentences (non-statistical procedure). It used systematic procedures to discover non-quantifiable relationship between existing variables (Singh, 2007:52). The research data derived from primary and secondary data including Bad Neighbors movie and some supporting documents as secondary data including journal articles and books.

In collecting the data, the movie was observed and identified. Orthographic transcription was conducted to change oral language to written language. The collected data were analyzed descriptively in depth description. The data were analyzed by identifying, reducing, classifying and explaining the data from movie Bad Neighbors. The description of the data analysis is as follow.

1. Identifying and reducing the collected data 
2. Classifying into the forms and the rules in using addressing terms and apologizing use as well as reducing them

3. Explaining the forms and the rules in using addressing terms and apologizing forms and strategy

4. Concluding

\section{FINDING}

In this study, the classification of American address terms found in the movie is based on the theories from Afful, Koul, politeness strategies by Brown and Levinson and variations from Li Yang. There are 9 categories of address terms found in movie Bad Neighbors. Based on the explanation in chapter II, Bad Neighbors tells the story about two now neighbors who had problems in their neighborhood. Therefore, the language is used by two sides are mostly informal language.

In the classification, address terms in this study are classified into 9 categories which will be explained as follow:

\section{Address Terms Based on Politeness Strategies}

There are two politeness strategies, namely, positive politeness and negative politeness. According to Brown and Levinson (in Kedves, 2013), in positive politeness, the speaker's goal is to address the positive face needs of the hearer whereas in negative politeness, the speaker avoids the imposition of the hearer. In positive politeness, the speakers expect an intimacy while in negative politeness the speakers maintain the respect and distance.

Address terms used in movie Bad Neighbors based on politeness strategies are explained in the following table.

Table 1.Address terms in negative politeness

\begin{tabular}{ll}
\hline \multicolumn{1}{c}{ Address Terms } & \multicolumn{1}{c}{ Function } \\
\hline Mrs. (Haywood) & $\begin{array}{l}\text { To address a married woman. Used in } \\
\text { formal situation }\end{array}$ \\
\hline Ma'am & $\begin{array}{l}\text { To address someone whom we respect. } \\
\text { Used in informal situation }\end{array}$ \\
\hline
\end{tabular}

The use of ma'am in the movie was in a tense-informal situation at the hospital when Kelly and Mac's daughter was sick. The doctor still maintained the manner to address stranger by using ma'am although he shouted by using 'hey!'. 
Kelly : Are you fucking kidding me? Who the fuck says that to a couple of parents?

Doctor : Hey! Ma'am!

Mac : Chill out, chill out! They are dangerous to the neighborhood!

Two address terms above includes in negative politeness strategy or positive face because in using the terms, speakers use it when they speak to someone whom they respect. They keep a distance to show respect to superior people.

Table 2.Address Terms in Positive Politeness

\begin{tabular}{ll}
\hline \multicolumn{1}{c}{ Address Terms } & \multicolumn{1}{c}{ Function } \\
\hline Mac/Stella/Kelly/Teddy & $\begin{array}{l}\text { To address someone with a close } \\
\text { distance }\end{array}$ \\
\hline Baby/sweetie & $\begin{array}{l}\text { To address someone with a very } \\
\text { close distance. } \\
\text { To show love and passion }\end{array}$ \\
\hline Pudgie/Scoonie & $\begin{array}{l}\text { To address someone by nickname } \\
\text { because of a very close distance }\end{array}$ \\
\hline Man/Guys/Dude/Brother/Fellas/Dawg & $\begin{array}{l}\text { To call a very close friends with a } \\
\text { very close distance. To shows } \\
\text { intimacy and bind. }\end{array}$ \\
\hline
\end{tabular}

Some address terms above shows the positive politeness or a negative face. As explained previously, positive politeness avoids the speakers' imposition of the hearers so that they keep a distant in the relationship to the hearers. The use of some terms above indicates an intimate relationship between the speaker and the hearer/interlocutor.

Pete : Tell 'em, Teddy.

Teddy : I'll tell you how. Do you see thatempty space on the wall? Let's fill it with dreams.

Pete and Teddy is close friend. Pete addressed Teddy by his first name/nick name because of the close relationship between both. Therefore, in this case, the term of address considered positive politeness.

\section{Variation of Apology}

There are two variations of apologizing explained in the research based on the directness and the 


\section{Direct apology}

Direct apology strategies refer to expressions that explicitly stated and direct + promise of forbearance (Li Yang, 2016). Data presentation can be seen in the table below:

Table 3.Type of apology according to Li Yang

\begin{tabular}{lccc}
\hline \multicolumn{1}{c}{ Type of apology } & Time & Example of expression & Frequency \\
\hline Direct & $00: 08: 38$ & $\begin{array}{c}\text { Kelly : good night. Excuse me. } \\
\text { Sorry. }\end{array}$ & 16 \\
\hline $\begin{array}{l}\text { Direct + promise of } \\
\text { forbearance }\end{array}$ & $00: 24: 47$ & $\begin{array}{c}\text { Mac : Okay, you know what? } \\
\text { Let's end this. I'm sorry. }\end{array}$ & 14 \\
& \multicolumn{3}{l}{$\begin{array}{l}\text { I resend the complaint. } \\
\text { You can go. }\end{array}$} \\
\hline
\end{tabular}

From the table above, direct apology has higher frequency in the use rather than direct + promise of forbearance form with 2 points difference. In direct apology, a shorten form of sorry indicates a more intimate relationship between the speakers. There was no term of address used in the expression. However, in direct + promise of forbearance above the use of I'm sorry present that a longer expression might indicate a lesser intimate relationship which contain a little respect but still in the casual style.

\section{Address Term and Apologizing in Bad Neighbors Position of Terms of Address in Apologizing}

American humor is American humor tends to be more "obvious" and less oblique, and can sometimes be considered by other English speaking cultures to be over the top and ridiculous. Americans do not understand irony; it is not the foundation of American humor. When Americans use irony they tend to state that they were "only kidding". They feel the need to make a humor more obvious than Brits do. Therefore, in this comedy movie the way to use the address term and apologizing strategy were most presented in an informal situation.

Formal situation indicates a high intimate relationship among the speakers. The movie presented some casual setting with low status. It presented a reciprocal $T u$ in using some informal style in expressing apology. It can be explained that even if the expressions were stated with or without some terms if address, they have different level of politeness consideration. 
The structure of the expression in apologizing presented some usage of address terms followed or preceded by the expression of apology such as:

1. Mac : "Never call us again? Look, man, we're sorry. You were being noisy. We tried to call you I don't know what to say.

2. Teddy : Sorry man, sorry my ball just got in your face.

The strategy in apologizing above is preceded and followed by the address term man whereas man is used in informal situation with a close relationship between the speakers. It shows positive politeness because the speakers explicitly apology and address someone without considering any higher level.

The distinct position of the terms of address above indicates the hidden purpose by the speaker. In (a), man was used preceding the expression of apology we're sorry. The purpose of this shift is to catch more attention from the interlocutor because of the sincerity of the speaker. It indicates that the speaker really means his word. Addressing someone at the beginning make the interlocutor pays attention to the speaker. Therefore, it is a strategy to assert sincere apology.

In contrast with (b), the term was used after the expression of apology. When the speaker said sorry preceding the term of address man, the message of apology was not stressed because it directly asserted without something that attract attention. Therefore, the quality of sincerity is considered to be lower than the preceded term of address.

\section{Zero Term of Address in Apologizing}

Most of term of address in the whole conversation from the excerpt presented zero address term in apologizing. It caused by the setting of speech. The speech situation presented casual and informal situation where the speakers felt intimate. The intimacy does not give a gap among the member in speech group. The situation is presented in the following excerpt.

\begin{tabular}{|c|c|}
\hline Mac & That's a joke! \\
\hline Policeman & good \\
\hline $\begin{array}{l}\text { Mac } \\
\text { complaint. }\end{array}$ & Okay, you know what? Let's end this. I'm sorry. I rescind the \\
\hline Policeman & $\begin{array}{l}\text { You can go. No noise complaint. } \\
\text { : You know the boy who cried wolf? You're that boy. }\end{array}$ \\
\hline
\end{tabular}


It can be inferred that the use of expression correspond to respect. In intimate relationship among the speakers, respect is sometimes neglected. It happens also in the situation above. Zero term of address in expressing apology indicates a low respect by the speaker upon his interlocutor. It may be caused by the age of the interlocutor which is younger than the speaker.

\section{DISCUSSION}

The strategy of apology and address terms applied by the character of "Bad Neighbors" movie can be identified through within each act of the use of both as proposed by Olsthain and Cohen (1983:45).

Meanwhile, the strategy of apology is absolutely needed by the offenders, when they perform the act of apologizing. The presence of the strategy of apology is useful to increase the effort to lessen the offense toward the offended or satisfy them. Meanwhile, Holmes (1992:78) considers apology as a speech act directed to the addressee's face need and intended to remedy an offensefor which the speaker takes responsibility, and thus to restore equilibriumbetween the speaker and addressee. Furthermore, the act ofapologizing was convivial speech act, the goal of which coincides with thesocial goal of maintaining harmony between speaker and hearer (Leech,1999:373). It will be useful to maintain the social harmony, which may be broken because of the past offensive act. The strategy of apology may be performed by means of an explicit apology, such as an expression of regret "I'm sorry", "I'm so sorry", and "I'm really sorry".

Address term may attach to many expressions in the conversation such as congratulating, condolence, asking and offering for help, apologizing, etc. However the use of this address term as well as the expression is bounded by the politeness strategy. Politeness may reflect the level of a speaker in the society based on the social status.

In the movie, Bad Neighbors reflected the real condition of certain society in Americans' life. It is a reflection of American society. The movie shows how people talk, greet, joke, and express the feeling through language. Since the movie genre is comedy, it can be identified how to state an apology and addressing others in humorous situation.

Based on finding, the movies contain informal and intimate situation with casual style. They leaned to joke with slang and taboo words. Therefore, most of the address term used to address someone is applied in informal situation and to someone who considered at the similar level. It was found that the informal address term was used after and before the apologizing expression. As in look, man, I'm sorry and in 
sorry, man the address term includes in positive politeness and direct + promise of forbearance. As reviewed in chapter II that in positive politeness the speaker considers the interlocutor is at the similar level with him. And direct + promise of forbearance, indeed, expressed when someone also feels a close relationship with the interlocutor.

Furthermore, speakers learned not to address others by applying the address terms. It means they applied zero address terms in most of expression of apology with a direct apology, such as We're sorry we called the cops, okay?. It indicates that the speaker wanted to show a more intimate relationship to the hearer when expressing apology. It can be inferred that to express apology, a speaker has to get more positive attention in saying sorry without intruding the hearer. Therefore, expressing apology with positive politeness which considered an intimacy seemed to be an appropriate strategy to assert an apology.

\section{CONCLUSION}

American humor in American comedy movie Bad Neighbors reflected a real situation in which Americans speak humor in a vulgar joke forms. Vulgarism and politeness are two different things but it could be analyzed to explain politeness in the informal situation presented in humorous way in a comedy movie.

The findings show that most of address terms were used included as positive politeness address terms such as term of intimacy man, dude, baby, etc. Related to the strategy of apologizing, they disposed to use direct apology but it did not show much difference. The use of address term also affected the purpose of apologizing. Preceded position of term indicates sincerity of the speaker and may catch more attention of the interlocutor. Meanwhile, a term was used after the expression of apology indicated a lower sincerity quality stated by the speaker.

Finally the use of address term in apologizing found in Bad Neighbors indicated the application of positive politeness address term in a direct apology. Most of expressions of apology were expressed with zero term of address because the speakers might get a positive attention (more intimate relationship) to the hearers without treating them in imposition way. 


\section{REFERENCES}

Afful, J. B. A. (2006). Address terms among university students in Ghana. A case Study. Journal of Language and Intercultural Communication, 6 (1), 76-91. Retrieved from www.njas.helsinki.fi/pdf-files/vol16num2/afful.pdf.

Aliakbari, M \& Toni, A. (2008). The realization of address terms in modern Persian in Iran: A sociolinguistic study. Linguistik online, 35 (3), 3-12, retrieved on February 15, 2016 from www.linguistik-online.net/35_08/aliakbari.pdf

Blum-kulka, S \& Olshtain, E. (1983). Request and apologies: A cross-cultural study of speech act realization patterns (CCSARP). Applied Linguistics, 5 (3),196213, retrieved on February 15, 2016 from socling.genlingnw.ru/files/smrp/CSARP\%20Blum-Kulka.pdf

Brown, P. and Levinson, S. (1987). Politeness. Retrieved from http://www.stanford.edu/tylers/notes/emoon/Brown_Levinson_1987_Politene ss_notes_Schnoebelen-pdf. Cambridge University.

Grigsby, K . (2007). The fine Art of Apology: When, Why and How to say" I'm Sorry". Retrieved February 15, 2016 from http://www.aamc.org/download/164762/data/grigsby_fine_art_of_apology .pdf.xdsr

Holmes, J. (1992). An introduction to sociolinguistics. New York: Longman Publishing.

Jan, S. (2013). Greeting, modes of address and politeness expression in kashmiri language: A cross-gender study. Dissertation. Srinagar: University of Kashmir, retrieved on April 10, 2016 from dspaces.uok.edu.in:8080/jspui/bitstream/1/1405/1/Saima\%20Jan.pdf

Johnstone, B. \& Marcellino, W. M. (2010). Dell Hymes and the ethnography of communication. Retrieved March $3 \quad 2015$ from repository.cmu.edu/cgi/viewcontent.cgi? article $=1013 \&$ contex $\mathrm{t}=$ english

Kedves, A. (2013). Face threatening acts and politeness strategies in summer school application calls. Jezikoslovlje, 14 (2/3). Retrieved from hrcak.srce.hr/file/165528

Leech, G. (1999). Principles of pragmatics. London: Longman.

Li Yang. (n.d). Direct apology strategies in Chinese. Retrieved on March 10 ${ }^{\text {th }}, 2016$ from https://www.kstate.edu/chinesepragmatics/apologies/2directapologystrategies.html

Maddux, W. (2011). CulturalDifferencesintheFunction andMeaningof Apologize. Retrieved from http://www.faculty.insead.edu/maddux/personal documents/INculturean.Apologies.pdf.France

Olshtain, E.\& Cohen, A. (1983). Apology: A speech act set. In N. Wolfson \& E. Judd (Eds.), Sociolinguistics and Language Acquisition, 18-35. Rowley, MA: Newbury House.

Quirk, R. (2014). Grammatical and lexical variance in English. New York: Routledge. 
Singh, Y.K. (2007). Research methodology. New Delhi: A.P.H. Publishing Company. Spencer-Oatey, H. (2004). Culturally speaking: managing rapport through talk across cultures. London: Continuum.

Wardaugh, R. (2000). An introduction to sociolinguistics. Oxford: Blackwell.

Yule, G. (2006). Pragmatik. Yogyakarta: Pustaka Pelajar. 